[Vicino Oriente XIX (2015), pp. 85-96]

\title{
EARLY CHRISTIANITY IN THE FAYYŪM: THE NEW CONTRIBUTION OF ARCHAEOLOGY*
}

\author{
Paola Buzi - Sapienza Università di Roma
}

\begin{abstract}
The article aims to suggest how, combining the possibilities offered by the Coptic literature and the new results of archaeological excavations and surveys, it is possible to improve our understanding of the early Christian Fayyüm, and of its northern part in particular.
\end{abstract}

Keywords: Fayyūm; Bakchias; Early Christianity; church architecture; monasticism

\section{EARLY CHRISTIANITY IN THE FAYYŪM: LITERARY SOURCES AND DOCUMENTARY SOURCES}

In his History of the Fayyūm, Abu 'Uthmân al-Nābulsī, governor of the pseudo-oasis on behalf of the last but one sovereign of the Ayyubid dynasty, and therefore excellent connoisseur of the whole province, documents the active existence, still in the $13^{\text {th }}$ century, of thirteen monasteries and twenty-five churches, confirming how deep and long-lived the roots of Christianity were in the area, despite the sometimes intolerant policy of the Islamic government. ${ }^{1}$

Likewise, the solidity of the binomial Fayyūm/Christianity, as observed by Arietta Papaconstantinou, is corroborated by the Apocalypse of the Pseudo-Samuel of Qalamūn, a passage of which states: "You will find none to read to the people, or to preach to them, because they will have forgotten the language and not understand what is read to them [...] even in Arsinoe, the great city which is in the Fayyūm». ${ }^{2}$

As is well known, the rapid and diffused spread of Christianity in the Fayyūm is attested to by a rich harvest of information, consisting of Greek, Latin, Coptic and Arabic documentary and literary texts.

As for the documentary evidence, the accurate survey conducted by Georg Schmelz does not leave much to be added. ${ }^{3}$ The literary evidence, on the other hand, is equally rich and various, but has not always had the attention that it deserves.

The History of the Fayyum is in fact only one of the most recent of the numerous literary sources describing the Christianisation of the Fayyūm: others deserving at least a mention are the fourth Letter of Antony, ${ }^{4}$ the anonymous Passio of Panine and Paneu, ${ }^{5}$ the Encomium of Apollo written by Stephen of Hnes ${ }^{6}$ and the Life of Samuel of Qalamūn attributed to Isaak of Qalamūn. ${ }^{7}$

* A shorter and preliminary version of this paper was delivered on the occasion of the Ninth International Congress of Coptic Studies.

Abou 'Osmân il Naboulsi il Safadi 1899; Abbott 1937, 57-58.

Papaconstantinou 2007, 276.

Schmelz 2004.

About the relationship between Antony and the Fayyum cfr. Wipszycka 2004.

Orlandi 1978.

Kuhn 1978.

7 Alcock 1983; Orlandi - Campagnano 1984; Orlandi 2006. 
These works must be added, of course, to the numerous manuscripts returned by the Fayyūm itself: the well known codices found in Hamūli in $1910,{ }^{8}$ the manuscripts discovered by Sir William Matthew Flinders Petrie in 1889 in the Monastery of the Virgin (later called Deir el-Hammām) and published by Walter Ewing Crum four years later, ${ }^{9}$ and the famous seven Manichean codices, found in Medīnet Mādi in $1929,{ }^{10}$ to mention but a few examples.

In a recent article, Anne Boud'hors has efficaciously explained the reasons why just a little number of these manuscripts preserves works written in Fayyūmic Coptic, providing a complete list of them. ${ }^{11}$

Both, the texts found in the Fayyūm itself and the ones which make reference to it, show the complexity of the religious situation in the region in the first centuries of Christian era. Concerning this specific aspect, Alberto Camplani, in an article dedicated to Alexandria and its suburbs, has stressed the specificity of the Fayyūm: a territory characterized by the presence of only one real town (Arsinoe) and, for the rest, by a plurality of small villages, and marked by a weak hierarchization which may have favoured the presence of groups of ecclesiastical and doctrinal dissent (Manicheans, Melitians, Anthropomorphists, etc.). ${ }^{12}$

The archaeological research, on the other hand, supports and improves the contribution of the textual evidence: starting with the excavations of Petrie through to the most recent archaeological works carried out by the numerous Egyptian and foreign missions which are active in the area, the knowledge of the cultural and social life of the late-antique Fayyūm has surely improved.

If we except the extraordinary contribution of the excavations conducted in Deir elNaqlūn, ${ }^{13}$ however, no more other archaeological expeditions working in the Fayyūm lateantique sites have been so lasting and systematic and have published their results so quickly until now. In particular not much is known about urban settlements, necropoleis and nonmonastic ecclesiastical buildings, to the point that the knowledge of the Christian Fayyum has still many grey areas. ${ }^{14}$

In addition, only rarely has the contribution of material culture been combined with that of literature, with the risk of creating a gap between the results of those who deal with texts and the results of those who work on the field.

Depuydt 1993, lv-lxxxix; Emmel 2005.

Crum 1893

10 Richter 2005.

1 Boud'hors 2005.

2 Camplani 2006.

13 The bibliography concerning the excavations carried out in Deir el-Naqlūn by the Polish Centre of Mediterranean Archaeology is extremely wide; we mention here just two recent contributions: Godlewski 2005a, 155-171 and Godlewski 2005b, 173-183.

14 For the few exceptions see Gabra ed. 2005; Godlewski - Lajtar 2006; Zych 2008. 


\section{ARCHAEOLOGY AND PHILOLOGY: A COMBINED METHOD FOR NEW RESULTS}

The purpose of these pages is to endeavour to suggest how, combining the possibilities offered by the Coptic literature and the new results of archaeological investigations, would make it possible to improve our understanding of the early Christian Fayyūm.

I mentioned before that the literary texts concerning the Fayyūm, above all the hagiographical ones, have not always been taken sufficiently into consideration as an instrument to investigate the historical and geographical reality of the region, while on the other hand, if we eliminate their fantastic elements, they often turn out to be extremely useful and trustworthy.

This is the case of the Life of Samuel of Qalamün, datable to the $7^{\text {th }}-8^{\text {th }}$ centuries. The story is long and elaborate: Samuel, born in the Delta, became a monk and hermit in Scetis, to abandon it when the new melkite patriarch, Cyrus, sent his legates there to convince the monks, where necessary with brutal means, to subscribe to the decisions taken during the Council of Chalcedon. Samuel refused to accept that imposition and therefore was tortured. He managed to escape, having received an apparition by an angel, suggesting him to reach the Fayyūm. He lived for some time at Deir el-Naqlūn, but the legates of the patriarch arrived there too. Samuel fled again, reaching the mount of Takinash, in the south-western fringe of the region, followed by some companions. There he found an abandoned church that would become the nucleus of the future Monastery of Qalamūn.

Despite Samuel's extraordinary adventures, the historical frame of the narration and the continuous reference to the dogmatic questions originating from the Council of Chalcedon are absolutely credible. But what is more interesting is that most of the narrative elements contained in this point of the story, when submitted to a geo-topographical survey, find a precise correspondence to the reality: the gebel where Samuel looks for a quiet and isolated dwelling leaving his companions in the valley; the marsh full of reeds - the same reeds from which the monastery take its name - where he takes refuge twice in order to escape, in vain, the Libyan tribe of the Mazikoi; the tracks connecting the south-western Fayyūm with Siwa (the so-called Amouniakè) and Lybia; the saline which allowed the monks to organise a trade in salt with the Nile Valley, creating the main income of Deir el-Qalamūn.

Concerning the saline, it is interesting to register that in 1178 Abu Salih the Armenian documents that the monastery was still able to produce 3000 artabas of salt per year. And even Muhammed al-Maqrīzī, in $15^{\text {th }}$ century, when the monastery was almost abandoned, confirms the production of salt. ${ }^{15}$ We also learn from the Life of Samuel that in Deir elQalamūn there lived a monk who was so sick that he had to be moved to Pemje (Oxyrhynchus), because the drinking water of the Fayyūm was extremely salty and therefore fatal for him.

The landscape description given by The Life of Samuel of Qalamün and the actual topography of the area appear therefore to match, and this makes reliable also other episodes of the Life, which are corroborated by material evidence, like the few architectural elements still visible scattered in the modern monastery of Qalamūn, chronologically and stylistically compatible with the construction of the monastery in the $7^{\text {th }}-8^{\text {th }}$ centuries.

15 Abbott 1937, 42. About the monastery and its foundation cfr. Smolenski 1908; Simon 1935; Fakhry 1947; Coquin - Martin - Grossmann 1991a, 758-760. Cfr. also Rāgheb 1995. 
The Encomium of Apollo is as useful as the Life of Samuel, although in this case the encomiastic aspect appears to be predominantly detrimental to the details relating to the topographic, archaeological and social context. The story takes place during the reign of Justinian (527-565), therefore once more the historical context is that of the Chalcedonian controversies. The author informs us that at the beginning Apollo was a monk in Pbow, from where he left, with Abraham, the archimandrite of the Pachomian monastery, because of the increasing number of monks who were ready to subscribe to the decisions taken by the Council of Chalcedon. After long wanderings, he reached the oriental part of the Fayyūm where he tried to found a new monastery, but his intention was obstructed by some Melitians "who were present in this mountain at that time, impeding by every means the settling of this saint». ${ }^{16}$

It is important to remember that we have other evidence of the presence of Melitians communities in the Fayyūm: ${ }^{17}$ three contracts concerning the property of some monasteries by Melitians found in Hawara and published by Brian C. McGing, ${ }^{18}$ the letter of Cyril to Calosiris, bishop of Arsinoe, mentioning the presence of this heterodox group of Christians in Qalamūn, ${ }^{19}$ and a passage of the Apophtegmata Patrum. ${ }^{20}$

Although the precise site of the monastery is not mentioned in the Encomium - the work states very generically that it is located north of Pbow - it was reasonable to look for it not far from Heracleopolis, seat of the supposed author of the work, Stephen of Heracleopolis, identifying it with the monastery founded by Apollo, nowadays denominated Deir elHammām or Monastery of the Virgin and located a few kilometres north-east of the pyramid of el-Lahūn. ${ }^{21}$

At first sight the modern monastery does not appear very promising regarding the conservation of its original architectural structures: it has been clearly transformed several times over the ages and it is even today under restoration. But under closer analysis it becomes clear that the original nucleus has still to be excavated, as is demonstrated by the numerous mud brick structures emerging from the sand and by the enormous quantity of pottery sherds scattered on the top of the whole kom (fig. 1).

In addition, a few months ago, the umpteenth restoration of the interior of the modern structure was rewarded with the recovery of some ancient architectural decorations, which may be stylistically attributed to the $6^{\text {th }}$ century, that is the time when the narration of the Encomium takes place (fig. 2).

\section{SOME NEW RESULTS FROM ARCHAEOLOGICAL WORKS CARRIED OUT IN THE NORTHERN FAYYŪM}

So far we have described the contribution of Coptic literature to the reconstruction of the archaeological context of the Fayyūm. But topographical surveys and archaeological

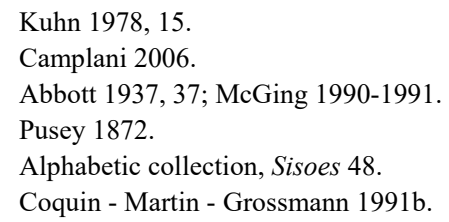


excavations in the northern part of the Fayyūm have recently added interesting amount of precious data to our knowledge of the region.

The joint archaeological mission of Bologna University and Sapienza University of Rome, for instance, combines its traditional excavation of the site of the Ptolemaic-Roman kome of Bakchias ${ }^{22}$ with a survey of the Christian settlements of the northern Fayyūm.

We will try, therefore, to give here a brief account of some of the new contributions of archaeology to the comprehension of the spread of Christianity in the region.

First of all, it is necessary to mention the late antique necropolis of Karanis, excavated in 2003 by a mission of the Inspectorate of the Fayyüm. The necropolis is located along the west side of the road connecting Cairo with Medinet el-Fayyūm and consists of five kiman, the top of which is occupied by truncated pyramid-shaped structures, arranged in parallel lines, but at irregular intervals. They are made of mud bricks plastered with clay and sometimes covered with some brief inscriptions. Among the pyramids, a few centimetres below the sand, the bodies are buried, all treated with a rough form of mummification. At first glance nothing seems to suggest the faith of the dead: all they have to be identified as Christians are the little crosses they have around their necks and some of the designs carved on the surface of the pyramids (fig. 3). The pottery found in the area suggests that the necropolis may have been used at least up to the $5^{\text {th }}-6^{\text {th }}$ centuries. From an architectural point of view, the necropolis of Karanis represents an unicum and documents the peculiarity of the forms of Egyptian Christian art in the region. ${ }^{23}$

The ecclesiastical architecture, which has its most famous examples in the numerous churches of Medīnet Mādi and Tebtynis (although in both cases a final report of the late antique and early mediaeval phase of the site is still lacking), ${ }^{24}$ has been recently enlarged by the discovery of two small churches in Bakchias and more precisely in the so-called south $\mathrm{kom}$, located beyond the canal originally running south of the main temple of the village, that of Soknobkonneus, and which was still clearly visible to the papyrologists Bernard P. Grenfell and Arthur S. Hunt. ${ }^{25}$

A previous survey had already identified this sector of Bakchias as a later suburb of the village, utilized above all for productive activities, as is confirmed by the numerous oil and wine presses and millstones found in the area. Then, in 2006 the mission explored an area that appeared promising for the presence of a column; this led to the discovery of the first church, and two years later to the finding of the second one. These are, at the moment, the only Christian buildings found at Bakchias and also the only ones found in the whole northern side of the Fayyūm (fig. 4).

The excavation yielded a small amount of evidence that allows us to state that the lifespan of the churches ranged from the $5^{\text {th }}$ to the $7^{\text {th }}$ centuries. Noteworthy among the retrievals are a fragmentary high quality equal-armed marble cross, a pluteus carved with floral elements, several fragments of decorated plaster, and a number of architectural

22 Giorgi - Buzi eds. 2014.

23 Buzi 2004, 97-106; 2006, 111-133.

24 As for Medīnet Mādi, an account of the late antique phase of the site is given in Bresciani et al. eds. 2006, 67127.

25 Grenfell - Hunt - Hogarth 1900, 35-42. 
limestone remains (columns, elaborated capitals, bases) unfortunately found spread over a wide area (fig. 5).

The two churches seem to be connected to one another, forming perhaps a single monastic complex: unfortunately, the site interpretation is complicated by the powerful overlay of different subsequent occupational phases and by the deterioration of structures to which the nearby modern village of Gorein has contributed. ${ }^{26}$

It is clear, however, that the Christian buildings of Bakchias have been reused at a later stage for productive purposes, as is well attested by the presence in the first church of a brickwork well, dug into the ground down to 4 metres of depth to reach the aquifer and by the construction of an oil press lined with hydraulic lime (evidence of the function of this structure is provided by pole holes for the press arbores, as well as by two settling basins set into the brickwork and fragments from a limestone pressing basin).

\section{TOPONYMS AS DOCUMENTARY AND ARCHAEOLOGICAL SOURCES}

In the absence of monumental archaeological remains or of literary evidence, traces of Christianisation must be patiently researched by means of any other signs, even if faint, like the toponymy, as, for example, in the area north of the Birket Qarūn, where, if we except the monastery of Deir Abu Lifa, the exact location of which, however, has been long discussed, ${ }^{27}$ nothing is sure.

Despite the silence of the literary sources, including al-Nābulsī, the area was surely inhabited by groups of Christians, as is demonstrated by the several dwellings scattered at the foot of the Gebel Qatrani, by the fragments of Coptic manuscripts found in different sites, or by the double toponym of 'Iluet al-Kanā'is al-Kabirah ("the big isle of the churches") e "Iluet al-Kanā'is al-Saghirah ("the small isle of the churches") (fig. 6). Nowadays the definition of islands for the two sites appears to be a nonsense, since they are both strongly connected to the coast, but when the level of the lake was higher than it is today the promontory of al-Kanā'is consisted in two islands, as it is shown in a map designed in 1717 and published by Maurice Martin. ${ }^{28}$ Of the late-roman settlement observed in al-Kanā'is by Gertrud Caton-Thompson in 1925 not much is left: the remains of rooms excavated in the limestone of the gebel, but totally filled by sand, some pottery sherds and fragments of wooden crosses.

The fact that neither al-Nābulsī nor any other literary evidence mentions Christian settlements in the area north of the Birket Qarūn is extremely meaningful and suggests that the progressive increase of salinity of the lake, and therefore of the desertification of the region, caused the abandonment of the area.

In the same way, it is interesting to remark that the enormous difference between the absolute absence of information regarding the area north of the Birket Qarūn and the abundant quantity of data concerning the southern and central areas of the region is a significant datum in itself.

26 Buzi 2007a, 21-39; 2007b, 93-103; 2007c, 377-392; 2009; 2014a, 69-80; 2014b, 179-211.

27 Munier 1937; Meinardus 1967-1968; Gallo 1993; Pernigotti 1997.

28 Martin 1987; Buzi 2008. 
Evidently, there is still a lot to be understood and clarified concerning the late antique phase of the Fayyūm: documents and literary texts are still to be read and interpreted, in the same way as archaeological contexts are still to be uncovered. Nevertheless, only by combining these two contributions can we substantially improve our knowledge of such a peculiar region and its religious and cultural development.

\section{REFERENCES}

Aввотт, N.

1937 The Monasteries of the Fayyum (Studies in Ancient Oriental Civilizations 16), Chicago 1937.

ABOU 'OSMÂN IL NABOULSI IL SAFADI

1899 Description du Faioum au VIIme siècle de l'Hégire (Publications de la Bibliothèque Khédiviale XI), Le Caire 1899.

Alcock, A.

1983 The Life of Samuel of Kalamun by Isaac the Presbyter, Warminster 1983.

BOUD'HORS, A.

2005 Manuscripts and Literature in Fayoumic Coptic: G. GABRA (ed.), Christianity and Monasticism in the Fayoum Oasis. Essays from the 2004 International Symposium of the Saint Mark Foundation and the Saint Shenouda the Archimandrite Coptic Society in Honor of Martin Krause, Cairo 2005, pp. 21-31.

Bresciani, E. - Giammarusti, A. - Pintaudi, R. - Silvano, F. (eds.)

2006 Medinet Madi. Venti anni di esplorazione archeologica (1984-2005), Pisa 2006.

BuZI, P.

2004 Lo scavo di una necropoli di età tardo-antica a Karanis (Kom Aushim): alcune annotazioni: Ricerche di Egittologia e Antichità copte 6 (2004), pp. 97-106.

2006 Ancora sulla necropoli tardo-antica di Karanis: indizi per la determinazione della datazione del definitivo abbandono del sito: S. PernigotTi - M. ZeCCHI (eds.), Atti del Colloquio "Il Coccodrillo e il Cobra. Aspetti dell'universo religioso egiziano nel Fayyum e altrove", Bologna 20-21 aprile 2005, Imola 2006, pp. 111-133.

2007a Bakchias XV. Rapporto preliminare della Campagna di scavo del novembre 2006: Ricerche di Egittologia e Antichità copte 9 (2007), pp. 21-39.

2007b Nuove considerazioni sul complesso ecclesiastico del kom sud: Ricerche di Egittologia e Antichità copte 9 (2007), pp. 93-103.

2007c Bakchias tardo-antica: la chiesa del kom sud: Aegyptus 87 (2007), pp. 377-392.

2008 Insediamenti cristiani a nord del Birket Qarun (Fayyum): il sito di al-Kanā'is: Ocnus 16 (2008), pp. 107-112.

2009 Una seconda chiesa a Bakchias. Nuove proposte interpretative sulla fase tardo-antica e cristiana della kome alla luce dei risultati della Campagna di scavo 2008: S. PERNIGOTTI E. Giorgi - P. BuZI (eds.), Rapporto preliminare della XVII Campagna di Scavo a Bakchias, Imola 2009, pp. 75-89.

2014a Fayyum tardo-antico e Bakchias cristiana: E. Giorgi - P. BUZI (eds.), Bakchias: dall'Archeologia alla Storia, Bologna 2014, pp. 69-80.

2014b Il settore cristiano: E. GioRgi - P. BuZI (eds.), Bakchias: dall'Archeologia alla Storia, Bologna 2014, pp. 179-211. 
CAMPLANi, A.

2006 Chiesa urbana e "periferie" cristiane di Alessandria nella tarda antichità: premesse per una ricerca: Annali di Storia dell'Esegesi 23/2 (2006), pp. 389-413.

COQuin, R.J. - MARTIN, M. - GRossmann, P.

1991a Dayr Anba Samu'il of Qalamun: A.S. AtrYA (ed.), The Coptic Encyclopedia, New York 1991, III, pp. 758-760.

1991b Dayr al-Hammam: A.S. AtrYA (ed.), The Coptic Encyclopedia, New York 1991, III, pp. 806-807.

CRUM, W.E.

1893 Coptic Manuscripts brought from the Fayyum by W.M. Flinders Petrie together with a DEPUYDT, L. papyrus in the Bodleian Library, London 1893.

1993 Catalogue of Coptic Manuscripts in the Pierpont Morgan Library, Leuven 1993.

EMMEL, S.

2005 The Library of the Monastery of the Archangel Michael at Phantoou (al-Hamuli): G. GABRA (ed.), Christianity and Monasticism in the Fayoum Oasis. Essays from the 2004 International Symposium of the Saint Mark Foundation and the Saint Shenouda the Archimandrite Coptic Society in Honor of Martin Krause, Cairo 2005, pp. 63-70.

FAKHRY, A.

1947 The Monastery of Kalamoun: Annales du Service des Antiquités d'Égypte 46 (1947), pp. 63-83.

GABRA, G. (ed.)

2005 Christianity and Monasticism in the Fayoum Oasis. Essays from the 2004 International Symposium of the Saint Mark Foundation and the Saint Shenouda the Archimandrite Coptic Society in Honor of Martin Krause, Cairo 2005.

Gallo, P.

1993 Il vero Deir Abu Lifa rivisitato: Egitto e Vicino Oriente XVI (1993), pp. 57-66.

Giorgi, E. - BUZI, P. (eds.)

2014 Bakchias: dall'Archeologia alla Storia, Bologna 2014.

GODLEWSKI, W.

2005a Excavating the ancient Monastery at Naqlun: G. GABRA (ed.), Christianity and Monasticism in the Fayoum Oasis. Essays from the 2004 International Symposium of the Saint Mark Foundation and the Saint Shenouda the Archimandrite Coptic Society in Honor of Martin Krause, Cairo 2005, pp. 155-171.

2005b The Medieval Coptic Cemetery at Naqlun: G. GABRA (ed.), Christianity and Monasticism in the Fayoum Oasis. Essays from the 2004 International Symposium of the Saint Mark Foundation and the Saint Shenouda the Archimandrite Coptic Society in Honor of Martin Krause, Cairo 2005, pp. 173-183.

GODLEWSKI, W. - ŁAJTAR, A.

2006 Grave stelae from Deir el-Naqlun: Journal of Juristic Papyrology 36 (2006), pp. 43-62.

Grenfell, B.B. - Hunt, A.S. - Hogarth, D.G.

$1900 \quad$ Fayûm Towns and Their Papyri, London 1900.

KuHN, K.H.

1978 A Panegyric on Apollo Archimandrite of the Monastery of Isaac by Stephen Bishop of Heracleopolis Magna (Corpus Scriptorium Christianorum Orientalium 394-395), Louvain 1978.

MARTIN, M.

1987 Un tour du Lac Qarūn en 1717. Qars el Sāga - Dimay - Qasr Qarūn: Bulletin de l'Institut Français d'Archéologie Orientale 87 (1987), pp. 265-268. 
MCGING, B.C.

1990-1991 An unusual monastic agreement from Byzantine Egypt: Manuscripts of the Middle East 5 (1990-1991), pp. 20-25.

MEINARDUS, O.

1967-1968 Dair Abû Lîfâ revisited: Bulletin de la Société d'archéologie copte 19 (1967-1968), pp. $177-181$.

MUNIER, H.

1937 Le Deir Abou-Lifa: Bulletin de l'Association des Amis des églises et de l'art coptes 3 (1937), pp. 1-5.

ORLANDI, T.

1978 Il dossier copto del martire Psote (Testi e documenti per lo studio dell'antichità 61), Milano 1978.

2006 Hagiographica Faiumica: S. PeRnigotTi - M. ZeCCHI (ed.), Il coccodrillo e il cobra. Aspetti dell'universo religioso egiziano nel Fayyum e altrove. Atti del colloquio, Bologna 20-21 aprile 2005, Imola 2006, pp. 41-51.

ORLANDi, T. - CAMPAgnano A.

1984 Vite di monaci copti (Collana di Studi Patristici 41), Roma 1984

PAPACONSTANTINOU, A.

2007 'They shall speak the Arabic language and take pride in it': Reconsidering the fate of Coptic after the Arab conquest: Le Muséon 120 (2007), pp. 273-299.

Pernigotti, $\mathrm{S}$.

1997 Ancora su Deir Abu Lifa: Papyrologica Lupiensia 5 (1997), pp. 249-258.

PUSEY, P.E.

1872 Sancti patris nostri Cyrilli archiepiscopi Alexandrini in D. Joannis Evangelium, Oxford 1872, III, pp. 603-607.

RAGHEB, Y.

1995 Les archives d'un gardien du monastère de Qalamūn: Annales islamologiques 29 (1995), pp. 25-57.

RICHTER, S.G.

2005 The Coptic Manichaean Library from Medinat Madi in the Fayoum: G. GABRA (ed.), Christianity and Monasticism in the Fayoum Oasis. Essays from the 2004 International Symposium of the Saint Mark Foundation and the Saint Shenouda the Archimandrite SCHMELZ, G. Coptic Society in Honor of Martin Krause, Cairo 2005, pp. 71-78.

2004 Das Christentum im Fayyum bis zum 5. Jahrhundert: Patristica et oecumenica. Festschrift für Wolfgang A. Bienert zum 65, Marburg 2004, pp. 147-156.

SIMON, J.

1935 Le monastère copte de Samuel de Kalamon: Orientalia Christiana Periodica 1 (1935), pp. 46-52.

SMOLENSKI, $\mathrm{T}$

1908 Le Couvent copte de St. Samuel à Galamun: Annales du Service des Antiquité de l'Égypte WIPSZYCKA, E. 9 (1908), pp. 204-210.

2004 La Vita Antonii confrontée avec la réalité géographique: U. ZANETTI - E. LUCCHESI (eds.), Aegyptus Christiana. Mélanges d'hagiographie égyptienne et orientale dédiés à la mémoire du P. Paul Devos bollandiste, Genève 2004, pp. 135-145.

ZYCH, I.

2008 Cemetery C in Naqlun: preliminary report on the excavation in 2006: Polish Archaeology in the Mediterranean 18 (2008), pp. 230-246. 


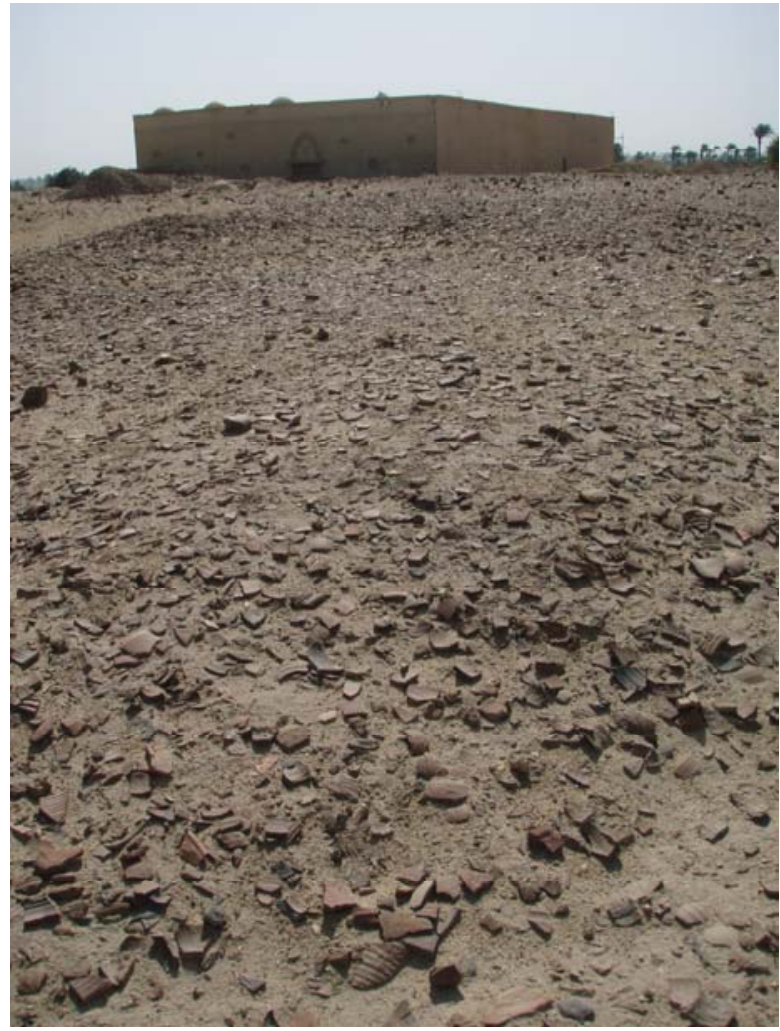

Fig. 1 - Pottery sherds scattered on the top of the kom in front of Deir el-Hammām (photo P. Buzi).

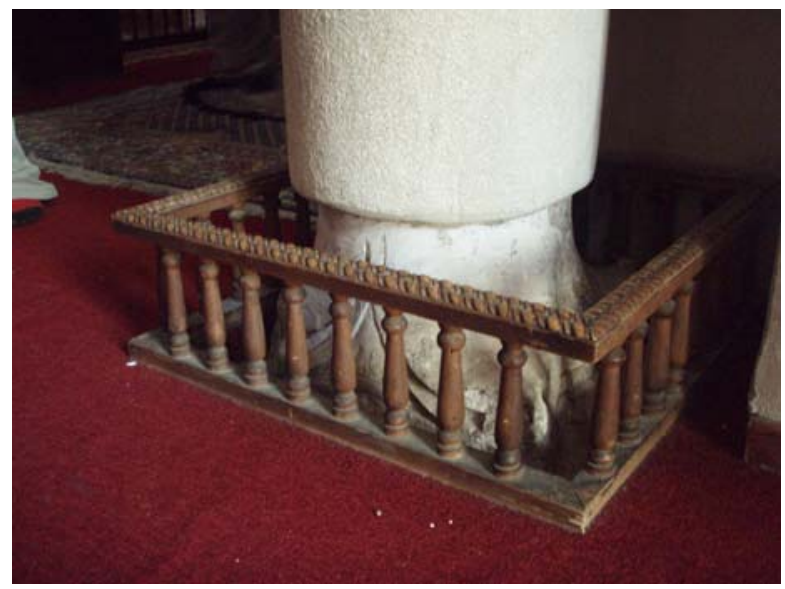

Fig. 2 - A $6^{\text {th }}$ century capital re-used as column basis in Deir el-Hammām (photo P. Buzi). 


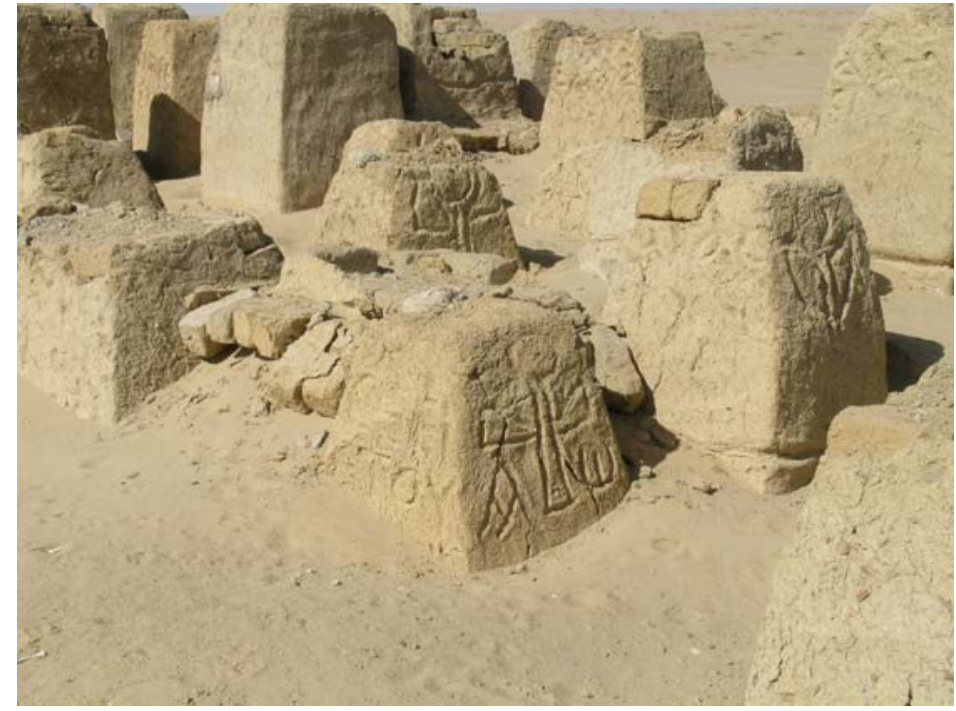

Fig. 3 - The late antique necropolis of Karanis, with its truncated pyramid-shaped structures (photo P. Buzi).

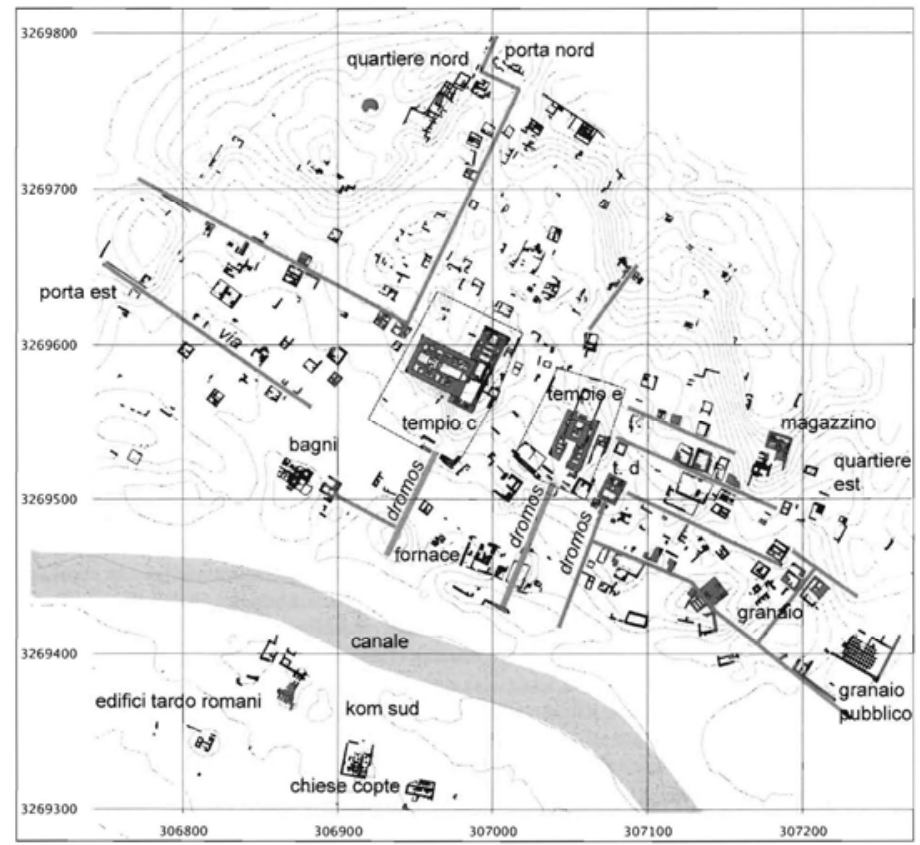

Fig. 4 - Map of the Ptolemaic-Roman Bakchias (Giorgi - Buzi eds. 2014, 59, fig. 4). 


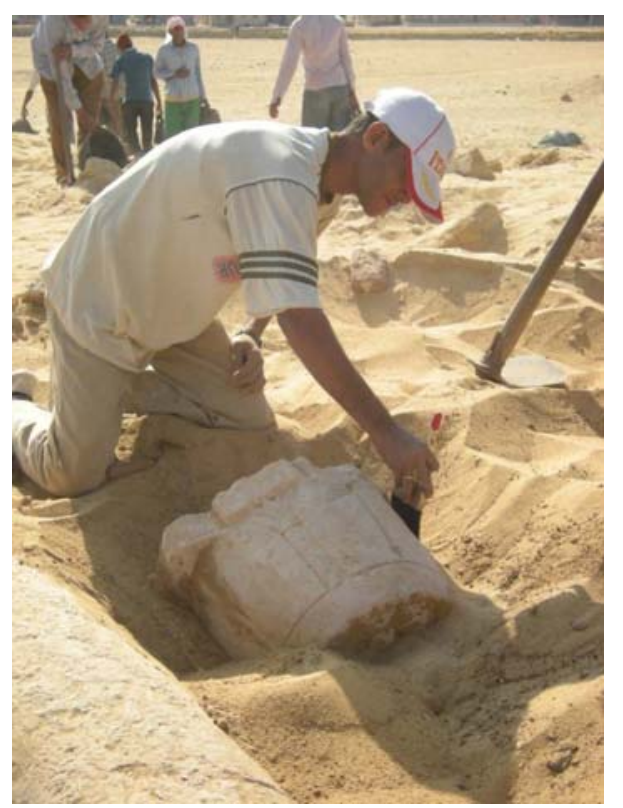

Fig. 5 - Capital from one of the churches of Bakchias (photo P. Buzi).

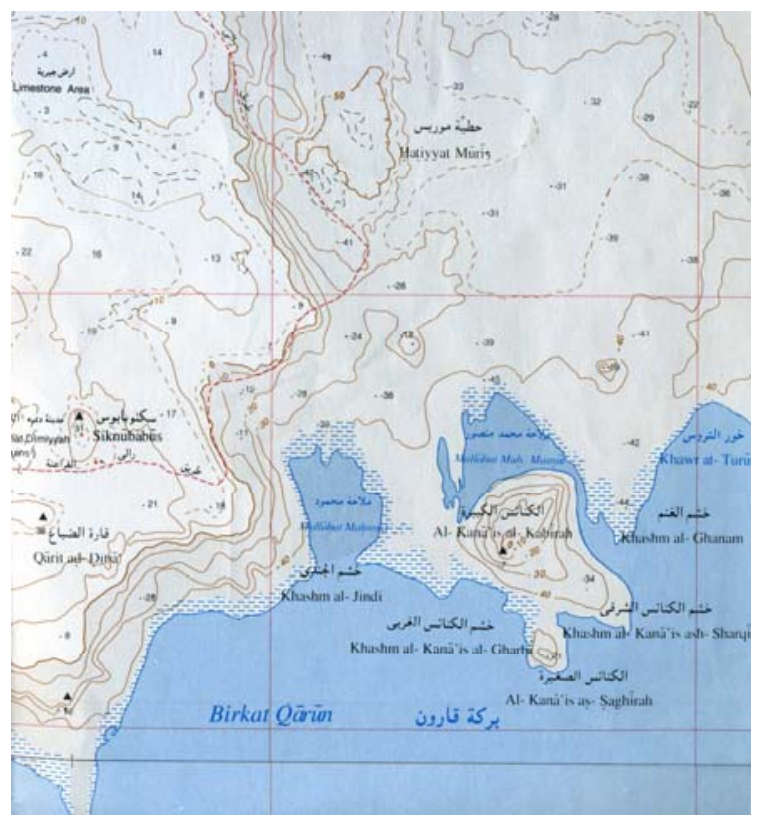

Fig. 6 - 1:50,000 map of the northern coast of the Birket Qarūn (NH36 E5a). 


\section{SOMMARIO}

DipartimENTo SCIENZE DELl'ANTICHITÀ

SEZIONE di ORIENTALISTICA

\section{VICINO ORIENTE \\ XIX - 2015}

L. Nigro - Bethlehem in the Bronze and lron Ages
in the light of recent discoveries by the Palestinian MOTA-DACH

$\checkmark$. Pisaniello - Parallel passages among Hittite-Luwian rituals:

for the restoration of $K U B 35.146$

F. Spagnoli - Una testa di sileno in bronzo da Mozia

N. Chiaren

dall Area sacra del Kothon a Mozia

G. Labisi - al-Fudayn: an Umayyad residence in Northern Jordan

P. Buzi - Early Christianity in the Fayyūm: the new contribution of archaeology

I. Materia - Preliminary notes on the ware depicted on the ceiling

of the Cappella Palatina in Palermo

S. Autiero - Indian Ocean trade:

a reassessment of the pottery find
$\left(3^{\text {rd }}\right.$ century $B C-S^{S^{t h}}$ century $\left.A D\right)$

M.M. Jamhawi - N. Al-Shakarchi - I. Al-Hashimi

Assessment of tourists' satisfaction in the downtown of Amman

SCAVI E RICERCHE

L. Nigro - C. Fiaccavento - M. Jaradat - J. Yasine

A

L. Nigro - D. Montanari - M. Ghayyada - J. Yasine

A Middle Bronze and Iron Age necropolis near Bethlehem (Palestine)

L. Nigro - G. Ripepi - I. Hamdan - J. Yasine

15 Interim Report

and valorization of archaeological heritage

R. Francia - L'archivio di tavolette del complesso B-C-H di Büyükkale

organizazione degli archivi reali ittiti. Considerazioni preliminari

V. Pisaniello - La collezione di tavolette del complesso B-C-H di Büyükkale

T. De Vincenzi - L'archivio di tavolette del complesso B-C-H
sull'acropoli di Büyükkale

Museo del Vicino Oriente, Egitto e Mediterraneo

L. Nigro - Il nuovo allestimento del Museo del Vicino Oriente,

Egitto e Mediterraneo della Sapienza

D. Montanari - Bollettino delle attività del Museo del Vicino Oriente,

Egito e Meditraneo della Sapienza, anno 2015

RECENSIONI

A. Orsingher - E. PAPPA (2013), Early Iron Age Exchange in the West:

(Ancient Near Eastern Studies Supplement Series 43)

Leuven - Paris - Walpole 2013, MA.: Peeters $\frac{1}{2}$

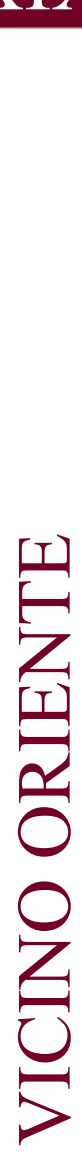

345

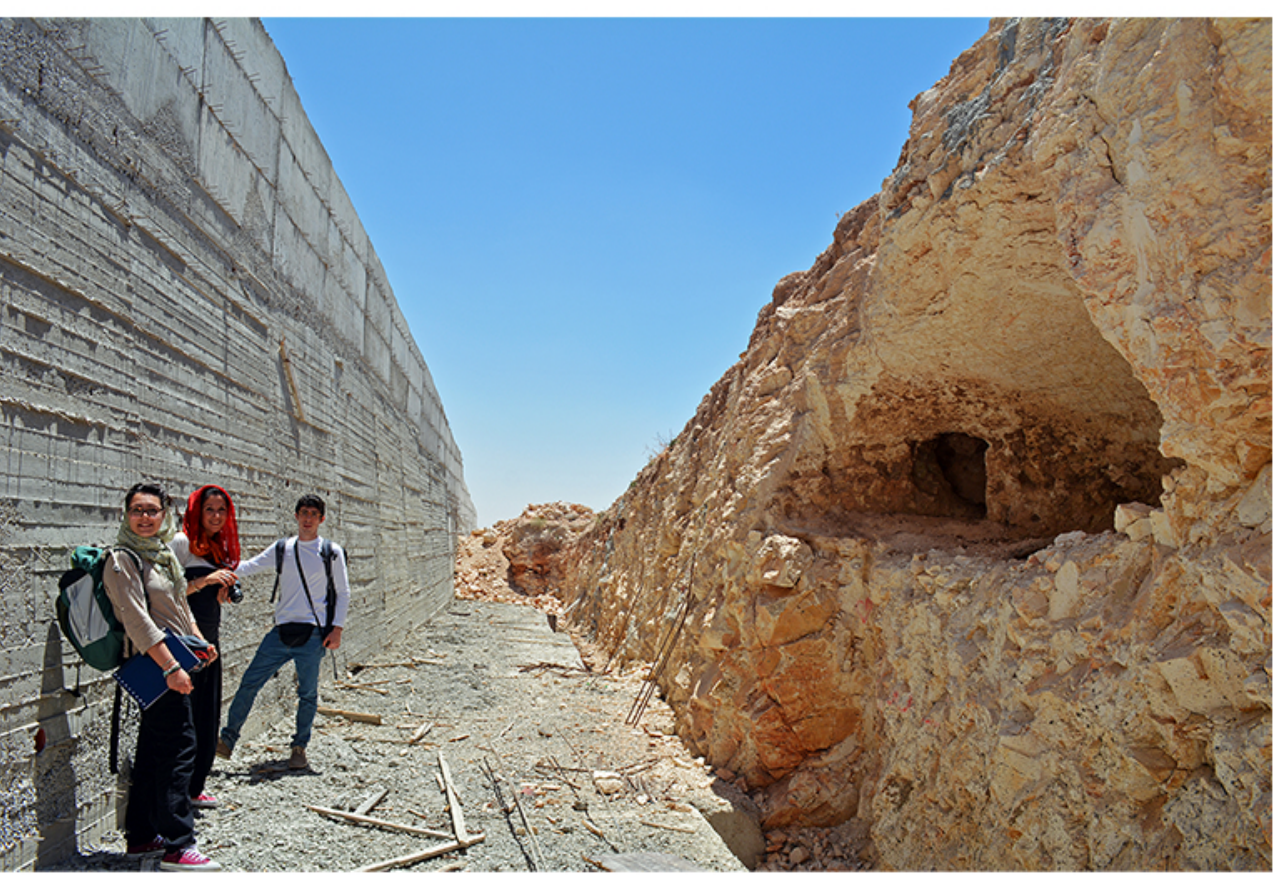

ROMA 2015 


\section{VICINO ORIENTE XIX - 2015}


VICINO ORIENTE

SAPIENZA UNIVERSITÀ DI ROMA

DIPARTIMENTO SCIENZE DELL'ANTICHITÀ

SEZIONE DI ORIENTALISTICA

Scientific Editor: Lorenzo Nigro

International Scientific Committee: Brian Rose, Frank Braemer, Mounir Fantar, Piero Bartoloni, Thomas Schaefer, Zeidan Kafafi

National Scientific Committee: Carlo Giovanni Cereti, Maria Vittoria Fontana, Sebastiano Tusa, Massimiliano Marazzi

Editorial Board: Daria Montanari, Chiara Fiaccavento

Tipografia: SK7 - Roma

ISSN 0393-0300

Rivista con comitato di referee

Journal with international referee system

www.lasapienzatojericho.it/SitoRivista/Journal/Rivista.php

In copertina: Tomba B9, necropoli di Khalet al-Jam’a (Betlemme). 
VICINO ORIENTE

SAPIENZA UNIVERSITÀ DI ROMA

DIPARTIMENTO SCIENZE DELL'ANTICHITÀ

SEZIONE DI ORIENTALISTICA

\section{SOMMARIO}

ARTICOLI

L. Nigro - Bethlehem in the Bronze and Iron Ages

in the light of recent discoveries by the Palestinian MOTA-DACH

V. Pisaniello - Parallel passages among Hittite-Luwian rituals:

for the restoration of KUB 35.146

F. Spagnoli - Una testa di sileno in bronzo da Mozia

N. Chiarenza - Una matrice per terrecotte con sileno dall'Area sacra del Kothon a Mozia

G. Labisi - al-Fudayn: an Umayyad residence in Northern Jordan

P. Buzi - Early Christianity in the Fayyūm: the new contribution of archaeology

I. Materia - Preliminary notes on the ware depicted on the ceiling

of the Cappella Palatina in Palermo

S. Autiero - Indian Ocean trade:

a reassessment of the pottery finds from a multidisciplinary point of view ( $3^{\text {rd }}$ century $B C-5^{\text {th }}$ century $\left.A D\right)$

M.M. Jamhawi - N. Al-Shakarchi - I. Al-Hashimi

Assessment of tourists' satisfaction in the downtown of Amman

SCAVI E RICERCHE

L. Nigro - C. Fiaccavento - M. Jaradat - J. Yasine Archaeology from A to Z: Abu Zarad, an ancient town in the heartland of Palestine

L. Nigro - D. Montanari - M. Ghayyada - J. Yasine

Khalet al-Jam'a. A Middle Bronze and Iron Age necropolis near Bethlehem (Palestine) 185 
VICINO ORIENTE

SAPIENZA UNIVERSITÀ DI ROMA

DIPARTIMENTO SCIENZE DELL'ANTICHITÀ

SEZIONE DI ORIENTALISTICA

L. Nigro - G. Ripepi - I. Hamdan - J. Yasine

The Jericho Oasis Archaeological Park - 2015 Interim Report.

Italian-Palestinian Cooperation for protection

and valorization of archaeological heritage

R. Francia - L'archivio di tavolette del complesso B-C-H di Büyükkale

e l'organizzazione degli archivi reali ittiti. Considerazioni preliminari

V. Pisaniello - La collezione di tavolette del complesso B-C-H di Büyükkale

T. De Vincenzi - L'archivio di tavolette del complesso B-C-H sull'acropoli di Büyükkale

Museo del Vicino ORIente, Egitto e MediterRaneo

L. Nigro - Il nuovo allestimento del Museo del Vicino Oriente,

Egitto e Mediterraneo della Sapienza

D. Montanari - Bollettino delle attività del Museo del Vicino Oriente,

Egitto e Mediterraneo della Sapienza, anno 2015

\section{RECENSIONI}

A. Orsingher - E. PAPPA (2013), Early Iron Age Exchange in the West:

Phoenicians in the Mediterranean and the Atlantic

(Ancient Near Eastern Studies Supplement Series 43),

Leuven - Paris - Walpole 2013, MA.: Peeters 